\title{
Pengembangan Lembar Kerja Siswa untuk meningkatkan Pemahaman Geometri Berbasis Pembelajaran Cooperative integrated reading and composition
}

\author{
Andang ${ }^{1}$, Dewi Silviana ${ }^{2}$ Arnasari Merdekawati \\ Program Studi Pendidikan Matematika STKIP Bima \\ Email: andangumm@gmail.com
}

\begin{abstract}
ABSTRAK
Tujuan penelitian ini adalah untuk menghasilkan perangkat pembelajaran berbentuk lembar kerja siswa dengan model pembelajaran Cooperative Integrated Reading and Composition guna meningkatkan pemahaman geometri dan mengetahui respon siswa terhadap lembar kerja siswa yang telah dikembangkan. Jenis penelitian ini merupakan penelitian pengembangan (Research and Development) dengan model Ploomp. Subjek uji coba lapangan meliputi 32 siswa kelas VIII-7 di SMP Negeri 1 Kota Bima. Instrumen penelitian yang digunakan terdiri dari lembar validasi, lembar observasi keterlaksanaan pembelajaran, lembar observasi aktivitas siswa, angket respons siswa, angket penilaian guru, dan tes pemahaman geometri. Hasil penilaian menunjukan bahwa perangkat pembelajaran dengan model Cooperative Integrated Reading and Composition (CIRC) pada materi geometri (lingkaran) di kelas VIII yang berbentuk LKS adalah valid dengan kategori sangat baik setelah dilakukan beberapa kali revisi, dinyatakan memenuhi kriteria kepraktisan setelah melalui tahap uji coba lapangan dengan rata-rata persentase aktivitas guru pada proses pembelajaran sebesar 4,38 atau berkategori baik dan respon siswa positif yang ditunjukan dengan minat dan ketertarikannya yang tinggi dalam mengikuti pembelajaran, dinyatakan efektif untuk digunakan dilihat dari tingkat pemahaman konsep siswa dengan ketuntasan klasikal 87,09\%.
\end{abstract}

Kata Kunci : Lembar Kerja Siswa, Pemahaman geometri, Kooperatif CIRC.

\begin{abstract}
The purpose of this study is to produce learning tools in the form of student worksheets with Cooperative Integrated Reading and Composition learning models in order to improve understanding of geometry and determine student responses to student worksheets that have been developed. This type of research is a research and development (Research and Development) with the Ploomp model. Field trial subjects included 32 students of class VIII-7 at SMP Negeri 1 Bima City. The research instrument used consisted of validation sheets, observations of learning outcomes, observation sheets of student activities, student response questionnaires, teacher assessment questionnaires, and geometry understanding tests. The results of the assessment show that the learning kit with the Cooperative Integrated Reading and Composition (CIRC) model on geometric material (circles) in class VIII in the form of worksheets is valid with a very good category after several revisions, declared to meet practical criteria after going through the field trial stage with an average percentage of teacher activity in the learning process of 4.38 or in the good category and positive student responses shown by their high interest and interest in participating in learning, it was declared effective to be used viewed from the level of students' understanding of concepts with classical completeness $87.09 \%$.
\end{abstract}

Keywords: Student Worksheets, Geometry Understanding, Cooperative CIRC.

\section{PENDAHULUAN}

Matematika merupakan ilmu yang tidak dapat dipisahkan dari dunia pendidikan dan mempunyai peranan yang sangat penting dalam mencetak SDM yang berkualitas karena matematika adalah ilmu yang berhubungan dengan penalaran dan pola pikir manusia. Matematika merupakan salah satu bagian dari ilmu dasar (basic science) yang memiliki peran penting di era kemajuan ilmu pengetahuan dan teknologi untuk mendukung 
pencapaian tujuan pendidikan nasional. Hal ini sesuai dengan Sowanto et all (2019) yang mengatakan bahwa matematika sebagai salah satu program pendidikan merupakan kesatuan ilmu yang mendukung pencapaian tujuan pendidikan nasional guna mencerdaskan kehidupan bangsa dan mengembangkan manusia Indonesia seutuhnya. Pembelajaran matematika diharapkan akan menjadi solusi akhir yang tepat, valid dan dapat diterima secara ilmiah oleh dunia pendidikan. Pendidikan matematika sangat penting diberikan kepada semua jenjang pendidikan, yang diharapkan dengan pendidikan matematika seseorang dapat memecahkan masalah dalam kehidupan sehari-hari.

Pembelajaran matematika seharusnya tidak hanya berorientasi pada hasil akhir, tetapi lebih menekankan pada proses selama kegiatan belajar mengajar berlangsung (Syahrir, 2016). Jika berkaca pada hasil PISA, Guru belum menekankan pada pengembangan daya nalar (reasoning), logika, dan proses berpikir kreatif. Bahkan hamper 80 persen pembelajaran Matematika dan sains di Indonesia berlangsung dengan metode ceramah. Hal tersebut sejalan hasil survei yang dilakukan oleh Proggrame for International Student Assesment (PISA) dari hasil tes dan evaluasi didapatkan bahwa performa pelajar Indonesia pada bidang matematika masih tergolong rendah yaitu peringkat 62 dari 69 negara yang dievaluasi dengan rata-rata 386 point yang termasuk pada kategori rendah dan jauh dari kategori mahir dengan rata-rata 625.

Sementara kemampuan siswa di SMPN 1 Kota Bima, diketahui bahwa dalam pembelajaran matematika sebagian siswa masih memiliki pemikiran bahwa matematika adalah mata pelajaran yang sulit sehingga dalam pelaksanaannya siswa cenderung malas dan tidak termotivasi dalam pembelajaran matematika. Hal tersebut sejalan dengan Yazid (2012) bahwa matematika masih dipandang sebagai ilmu pengetahuan yang bersifat deduktif aksiomatik dan obyeknya bersifat abstrak, dan cenderung sulit dipahami oleh siswa. Pemikiran yang seperti itu jelas akan mempengaruhi terhadap penguasaan materi serta hasil belajar pada matematika. Pembelajaran matematika yang cenderung dianggap sulit oleh sebagian siswa tersebut membuat siswa merasa bosan dalam pembelajaran matematika karena hanya sebatas soal perhitungan baik penjumlahan, pengurangan, perkalian dan pembagian. Kurangnya bekerja sama positif dalam menyelesaikan tugas kelompok. Selain itu guru masih menggunakan metode ceramah dalam pembelajaran matematika, sehingga siswa hanya menerima informasi dari guru dan pembelajaran matematika masih didominasi oleh guru (teacher centered) dan guru juga belum pernah mencoba menggunakan media pembelajaran. 
Menurut (Hotimah et all, 2014), upaya yang bisa dilakukan untuk meningkatkan pemahaman siswa dan mengatasi kesulitan siswa adalah dengan menggunakan model pembelajaran yang menekankan proses pembelajarannya terhadap pemahaman bacaan dan menyiapkan perangkat pembelajaran, salah satunya adalah Cooperative Integrated Reading and Composition (CIRC). Pembelajaran kooperatif CIRC dilaksanakan agar dapat menciptakan suasana belajar yang menyenangkan dan membuat siswa mampu menggunakan daya pikirnya sehingga siswa meningkatkan kemampuan pemahamannya khususnya pada materi geometri. Menurut Acek (2019) penerapan model pembelajaran kooperatif tipe CIRC ini lazimnya menimbulkan suasana belajar yang lebih menyenangkan. Hal ini karena siswa belajar dan saling bertukar pikiran dengan temannya sendiri. Selain itu, diharapkan juga siswa bisa berpikir kreatif melalui interaksi dengan teman sehingga dapat menyelesaikan masalah dengan sistematis. Karimah (2017) menyatakan model pembelajaran CIRC menuntut siswa belajar secara berkelompok dan guru memberikan materi untuk dipahami oleh siswa kemuadian mereka menyusun kembali pemahaman materi yang sudah didiskusikan dengan kelompoknya dan dituangkan dalam kalimat sendiri. Tujuan utama dari CIRC adalah menggunakan tim-tim kooperatif untuk membantu siswa dalam mempelajari kemampuan memahami bacaan yang dapat diaplikasikan secara luas.

\section{METODE PENELITIAN}

Penelitian ini termasuk penelitian pengembangan (research development). Rochmad (2012) menyebut para ahli pendidikan memendang penelitian pengembangan berbeda dengan jenis penelitian lainnya. Pendekatan penelitian misalnya eksperimen, survey, dan analisis korelasional oleh van den Akker digolongkan dalam pendekatan penelitian tradisional yang memfokuskan pada pengetahuan diskriptif dan kurang menekankan pada kepraktisan. Berbeda dengan penelitian tradisional, penelitian pengembangan menekankan pada keduanya kontribusi praktis (practical constribution) dan kontribusi ilmu pengetahuan (scientific constribution). Metode penelitian pengembangan adalah metode penelitian yang digunakan untuk menghasilkan produk tertentu sekaligus menguji kevalidan, kepraktisan dan keefektifan produk tersebut (Hadi et all, 2018). Penelitian ini akan dilaksanakan di SMPN 1 Kota Bima. Adapun prosedur pengembangan perangkat pembelajaran menggunakan model pengembangan Plomp yang dikembangkan oleh Van den Akker dan Plomp. Tahapannya terdiri dari tahap investigasi awal (Prelimery Investigation), tahap perancangan (Design), tahap realisasi (Realization/ 
Construction), tahap uji coba, evaluasi dan perbaikan (Test, Evaluation and Revision) dan tahap penerapan (Implementation). Peneliti memilih menggunakan model Plomp ini karena model penelitian ini memfokuskan pada pengembangan perangkat pembelajaran agar dapat diaplikasikan dalam penelitian berbasis pembelajaran di sekolah. Instrumen yang digunakan dalam penelitian ini adalah 1) Lembar Validasi Perangkat Pembelajaran. Lembar validasi yang digunakan adalah lembar untuk menilai produk prototype berbentuk draf LKS untuk dapat menentukan pemenuhan standar kepraktisan dan efektivitasnya. 2) Lembar Angket, Angket validasi produk yaitu angket untuk penilaian produk lembar kerja siswa (LKS). Angket yang digunakan terdiri dari dua bagian, yaitu kolom check list meliputi daftar penilaian dan skala penilaiannya serta lembar komentar, tanggapan, kritik dan saran dari validator. Untuk menganalisis data pengembangan perangkat pembelajaran, teknik yang digunakan adalah analisis deskriptif. Data yang dianalisis adalah 1) Analisis data validasi. Data hasil validasi para ahli untuk masingmasing format perangkat pembelajaran dianalisis dengan mempertimbangkan penilaian, masukan, komentar dan saran-saran dari validator. Hasil analisis tersebut dijadikan sebagai pedoman untuk revisi perangkat pembelajaran. Tingkat validitas masing-masing perangkat pembelajaran ditentukan dengan melibatkan hasil penilaian semua validator. Analisis dilakukan teradap semua butir penilaian yang telah dilakukan oleh masingmasing validator, dengan membuat rekapitulasi skor dan kemudian menentukan rata-rata tiap aspek penilaian berdasarkan rata-rata setiap butir penilaian semua validator. Selanjutnya menentukan rata-rata total berdasarkan rata-rata setiap aspek penilaian. 2) Analisis Data Kepraktisan. Ditentukan berdasarkan penilaian validator dengan kriteriakriteria yaitu dapat digunakan tanpa revisi, dapat digunakan dengan revisi kecil, dapat digunakan dengan revisi besar, dan belum dapat digunakan masih memerlukan konsultasi. 3) Analisis angket. Analisis data yang digunakan untuk mengolah data perolehan dari angket validasi produk pengembangan bersifat Statistik deskriptif. Data kuantitatif dari tiap-tiap item instrumen dihitung dengan menggunakan teknik analisis nilai rata-rata.

\section{HASIL DAN PEMBAHASAN}

Suatu produk yang dikembangkan harus dikatakan praktis agar layak digunakan dalam proses pembelajaran. Menurut Nieveen, karakteristik produk pendidikan yang memiliki kualitas kepraktisan yang tinggi apabila ahli atau guru mempertimbangkan produk itu dapat digunakan dan dalam penggunaannya menunjukkan bahwa mudah bagi 
guru dan peserta didik untuk menggunakan produk tersebut. Hal ini berarti terdapat konsistensi antara harapan dengan pertimbangan dan harapan dengan operasional. Apabila kedua konsistensi tersebut tercapai, maka produk hasil pengembangan dapat dikatakan praktis.

Kepraktisan perangkat pembelajaran yang dikembangkan pada penelitian ini didasarkan pada penilaian para ahli (validator) dengan cara mengisi lembar validasi masing-masing perangkat pembelajaran. Dalam penelitian ini, perangkat pembelajaran dikatakan praktis jika validator mengatakan perangkat tersebut dapat digunakan dengan sedikit atau tanpa revisi. Pengembangan Perangkat Pembelajaran dalam penelitian ini adalah menggunakan model Ploomp. Ada lima tahapan, yakni prelimery investigation, design, realization, test evaluation, revisi and implementation. Adapun kegiatan yang dilakukan pada tahapan-tahapan tersebut, sebagai berikut:

\section{Tahap Investigasi Awal (Prelimery Investigation)}

Tahap investigasi awal (prelimery investigation) di SMP Negeri 1 Kota Bima pada semester genap tahun ajaran 2017/2018. Kepala sekolah dan seluruh guru dan staf menerima baik maksud dan tujuan hadirnya peneliti. Peneliti diberikan izin untuk meneliti di kelas VIII ${ }^{7}$ dan menunjuk Bapak Junaidin, S.Pd sebagai guru pembimbing. Jumlah siswa di kelas VIII $^{7}$ sebanyak 32 orang dengan jumlah pria sebanyak 15 orang dan wanita sebanyak 17 orang dengan kemampuan heterogen. Peneliti diberikan kebebasan untuk meneliti di setiap jam pelajaran matematika dan bisa datang kapanpun selama masih dalam jam sekolah sesuai kepentingan peneliti.

Peneliti mengembangkan perangkat pembelajaran dengan tujuan melihat peningkatan pemahaman siswa. Oleh karena itu, peneliti mencari informasi yang berkaitan dengan pemahaman siswa. Pemahaman siswa dipengaruhi oleh beberapa aspek, yakni motivasi belajar, minat belajar, perhatian dan konsentrasi, apersepsi, kecerdasan serta kemampuan siswa. Pada saat peneliti memasuki kelas VIII ${ }^{7}$ untuk pertemuan awal, dapat disimpulkan bahwa motivasi belajar siswa kurang, hal ini dinilai dari banyaknya siswa yang tidak mengerjakan tugas rumah yang diberikan oleh guru. Hanya beberapa siswa yang mengerjakan tugas. Minat belajar siswa dinilai berdasarkan banyaknya siswa yang memperhatikan saat proses pembelajaran berlangsung. Dengan memperhatikan minat belajar siswa dapat dilihat pula perhatian dan konsentrasi belajar siswa dalam kelas. Namun, pada aspek apersepsi, kecerdasan serta kemampuan siswa cukup baik. Hal ini dapat dilihat ketika siswa bekerja sama dalam kelompok dan cara menafsirkan masalah dengan memanfaatkan kemampuan berpikirnya saat mengerjakan tugas dari peneliti. 
Materi geometri dengan pokok bahasan lingkaran dipilih oleh peneliti sebagai materi pembelajaran dengan indikator sebagai berikut: 1) Mengidentifikasi unsur-unsur lingkaran, 2) Mengidentifikasi hubungan antar unsur-unsur pada lingkaran, 3) Menyelesaikan permasalahan yang terkait dengan unsur-unsur lingkaran, 4) Menentukan keliling lingkaran, 5) Menentukan luas lingkaran, 6) Menyelesaikan permasalahan yang terkait dengan keliling dan luas lingkaran, 7) Menemukan hubungan antara sudut pusat dengan sudut keliling yang menghadap busur sama, 8) Menemukan hubungan antara sudut keliling yang menghadap busur sama, 9) Menemukan hubungan antara sudut keliling yang menghadap busur sama, 10) Menemukan hubungan sudut yang saling berhadapan pada segiempat tali busur, 11) Menentukan hubungan sudut pusat dengan panjang busur, 12) Menentukan hubungan sudut pusat dengan luas juring, 13) Menentukan garis singgung persekutuan dalam dan garis singgung persekutuan luar dua lingkaran.

Pada tahapan ini pula peneliti menganalisis bahwa model pembelajaran Cooperative Integrated Reading and Composition (CIRC) belum pernah diterapkan oleh guru mata pelajaran matematika. Model pembelajaran Cooperative Integrated Reading and Composition (CIRC) menuntut siswa untuk aktif membaca, menulis dan seni berbahasa. Peneliti juga menggunakan model pembelajaran Cooperative Integrated Reading and Composition (CIRC) karena beberapa kelebihan dari model tersebut, yakni: 1) Pengalaman dan kegiatan belajar peserta didik (siswa) akan selalu relevan dengan tingkat perkembangan anak, 2) Kegiatan yang dipilih sesuai minat siswa dan kebutuhan anak, 3) Seluruh kegiatan belajar lebih bermakna bagi siswa sehingga hasil belajarnya akan dapat bertahan lebih lama, 4) Pembelajaran terpadu dapat menumbuh-kembangkan keterampilan berpikir anak, 5) Pembelajaran terpadu menyajikan kegiatan yang bersifat pragmatis (bermanfaat) sesuai dengan permasalahan yang sering ditemui dalam lingkungan anak, 6) Pembelajaran terpadu dapat menumbuhkan motivasi belajar siswa ke arah belajar yang dinamis, optimal dan tepat guna, 7) Menumbuh kembangkan interaksi sosial anak seperti kerjasama, toleransi, komunikasi dan respek terhadap gagasan orang lain, 8) Membangkitkan motivasi belajar, memperluas wawasan dan aspirasi guru dalam mengajar.

\section{Tahap Perancangan (Design)}


Peneliti menganalisis perangkat pembelajaran apa saja yang akan dikembangkan sesuai hasil investigasi awal di SMP Negeri 1 Kota Bima. Peneliti memutuskan untuk mengembangkan perangkat pembelajaran, salah satunya berupa draf LKS. Draf LKS tersebut dikembangkan berdasarkan pembelajaran Coperatif CIRC. Lembar Kegiatan Siswa dikembangkan dengan tujuan untuk membantu peserta didik menemukan konsep, menerapkan dan mengintegrasikan berbagai konsep yang telah ditemukan, penuntun belajar, paktikum, dan sebagai penguatan terhadap materi geometri. Lembar Kerja Siswa berpedoman pada buku cetak atau sumber lain yang sesuai dengan konsep dan prinsip materi pokok lingkaran yang disusun sebanyak 7 LKS terdiri dari 13 kegiatan. Pada LKS terdapat aturan diskusi kelompok dan langkah-langkah pembelajaran Cooperative Integrated Reading and Composition (CIRC) yang diharapkan dapat menjadi panduan bagi siswa dalam mengikuti kegiatan pembelajaran. Selain lembar kerja siswa, dalam penelitian ini juga dikembangkan tes pemahaman geometri yang diperlukan untuk mengetahui tingkat pemahaman siswa setelah belajar menggunakan LKS yang dikembangkan. Perangkat pembelajaran yang telah dikembangkan dijadikan sebagai produk awal dan belum direvisi. Selanjutnya akan divalidasi terlebih dahulu oleh ahli dan praktisi untuk mengetahui kelayakan (validitas) produk awal sebelum dilakukan uji coba.

3. Tahap Realisasi, Uji coba, Evaluasi dan Perbaikan

Draf LKS dikembangkan dengan tujuh kali pertemuan draf yang dihasilkan tersebut disebut protoypt pertama. Prototypt yang dihasilkan kemudian dinilai atau divalidasi oleh validator dengan beberapa aspek, meliputi: materi pelajaran, bahasa yang digunakan, ilustrasi, dan kebenaran atau kelogisan isi. Ada 3 orang yang berperan sebagai validator. Validator yang diminta kesediaan waktunya untuk menilai adalah ahli matematika yakni Bapak Murtalib, M.Pd dan Ibu SriAryaningsyih, M.Pd, sementara Bapak Junaidin, S.Pd merupakan guru matematika. Tugas validator adalah menilai aspek dan kriteria, sudahkah sesuai dengan apa yang dituangkan kedalam perangkat pembelajaran yang dikembangkan oleh peneliti. Penilaian dari validator nantinya dihitung secara kuantitatif kemudian dideskripsikan secara kualitatif.

Tabel 4.1 Jenjang Kriteria Penilaian Validitas Aspek dan Kriteria

\begin{tabular}{cc}
\hline Rentang Nilai Kuantitatif & Kualitas Kualitatif \\
\hline $4,5 \leq \mathrm{M} \leq 5$ & Sangat Valid \\
\hline $3,5 \leq \mathrm{M} \leq 4,5$ & Valid \\
\hline $2,5 \leq \mathrm{M} \leq 3,5$ & Cukup valid (revisi kecil) \\
\hline $1,5 \leq \mathrm{M} \leq 2,5$ & Kurang valid (revisi besar) \\
\hline $\mathrm{M} \leq 1,5$ & Tidak Valid (revisi total) \\
\hline
\end{tabular}

Sumber: Nurdin, 2007 
Pada tahap awal penelitian, peneliti melakukan diskusi dengan guru mata pelajaran, melakukan kajian terhadap karekteristik pembelajaran matematika di SMP Negeri 1 Kota Bima untuk mengetahui problem dalam pembelajaran matematika, menentukan bagaimana bentuk perangkat pembelajaran LKS, mevalidasi perangkat pembelajaran yang dikembangkan oleh validator, serta melakukan perbaikan atau revisi berdasarkan penilaian dan saran dari validator.

Penilaian validator terhadap draf LKS meliputi format pengembangan materi pelajaran, bahasa yang digunakan, ilustrasi, dan kebenaran dan kelogisan isi. Hasil penilaian secara singkat disajikan berikut:

Tabel 1. Hasil Validasi Prototypt Pertama dari 3 Validator

\begin{tabular}{clcc}
\hline No. & \multicolumn{1}{c}{ Aspek } & Rata-rata & Keterangan \\
\hline 1. & Format Materi & 2,6 & Kurang Valid \\
\hline 2. & Bahasa yang digunakan & 2,5 & Kurang Valid \\
\hline 3. & Ilustrasi & 2,4 & Cukup Valid \\
\hline 4. & Kebenaran dan Kelogisan Isi & 3,2 & Valid \\
\hline & Rata-rata & 2,6 & Cukup Valid
\end{tabular}

Sumber: Data Primer Olahan, 2018

Hasil penilaian kepraktisan perangkat pembelajaran LKS yang dikembangkan berdasarkan penilaian validator disajikan dalam tabel berikut:

Tabel 2. Hasil Penilaian Kepraktisan Perangkat Pembelajaran

\begin{tabular}{|c|c|c|c|}
\hline Perangkat Pembelajaran & Validator & Nilai & Keterangan \\
\hline \multirow{3}{*}{ Draf LKS } & 1 & $\mathrm{C}$ & \multirow{3}{*}{$\begin{array}{l}\text { Dapat Digunakan } \\
\text { dengan revisi besa }\end{array}$} \\
\hline & 2 & $\mathrm{C}$ & \\
\hline & 3 & $\mathrm{C}$ & \\
\hline
\end{tabular}

Sumber: Data Primer Olahan, 2018

Berdasarkan Tabel 2 diatas, dapat disimpulkan bahwa perangkat pembelajaran LKS yang dikembangkan dapat digunakan dengan banyak revisi dan masih belum dapat dikatakan praktis. Prototypt harus direvisi kembali, kemudian prototypt kedua hasil revisi kembali divalidasi oleh validator.

Setelah dilakukan revisi pada prototyp pertama dengan menambahkan langkahlangkah agar sesuai dengan model pembelajaran CIRC, menghilangkan soal atau materi yang bersifat ganda, dan memperjelas alokasi kegiatan, peneliti meminta validator untuk melakukan penilaian kembali prototyp yang telah direvisi. Penilaian dilakukan oleh 
validator terhadap prototypt kedua dengan aspek yang sama meliputi format pengembangan materi pelajaran, bahasa yang digunakan, ilustrasi, dan kebenaran atau kelogisan isi. Hasil penilaian secara singkat disajikan dalam tabel berikut:

Tabel 3. Hasil Validasi Prototypt Kedua dari 3 Validator

\begin{tabular}{clcc}
\hline No. & \multicolumn{1}{c}{ Aspek } & Rata-rata & Keterangan \\
\hline 1. & Format Materi & 3,1 & Cukup Valid \\
\hline 2. & Bahasa yang digunakan & 3,2 & Cukup Valid \\
\hline 3. & Ilustrasi & 3,2 & Cukup Valid \\
\hline 4. & Kebenaran dan Kelogisan Isi & 3,7 & Valid \\
\hline & Rata-rata & 3,3 & Cukup Valid \\
\hline
\end{tabular}

Sumber: Data Primer Olahan, 2018

Hasil penilaian kepraktisan perangkat pembelajaran LKS yang dikembangkan berdasarkan penilaian validator disajikan dalam tabel berikut:

Tabel 4. Hasil Penilaian Kepraktisan Perangkat Pembelajaran

\begin{tabular}{cccl}
\hline Perangkat Pembelajaran & Validator & Nilai & \multicolumn{1}{c}{ Keterangan } \\
\hline Draf LKS & 1 & B & $\begin{array}{l}\text { Dapat digunakan dengan revisi } \\
\text { kecil }\end{array}$ \\
\cline { 2 - 4 } & 2 & B & $\begin{array}{l}\text { Dapat digunakan dengan revisi } \\
\text { kecil }\end{array}$ \\
\cline { 2 - 4 } & 3 & C & $\begin{array}{l}\text { Dapat digunakan dengan revisi } \\
\text { besar }\end{array}$ \\
\hline
\end{tabular}

Sumber: Data Primer Olahan, 2018

Berdasarkan tabel 4 diatas, dapat disimpulkan bahwa Perangkat Pembelajaran LKS yang dikembangkan dapat digunakan dengan banyak revisi dan masih belum dapat dikatakan praktis karena validator ketiga masih menilai prototypt dengan nilai $\mathrm{C}$ yang berarti prototypt harus direvisi kembali. Kemudian prototypt ketiga kembali divalidasi oleh validator setelah dilakukan revisi. Penilaian prototyp ketiga dilakukan oleh validator dengan aspek yang sama. Hasil penilaian secara singkat disajikan dalam tabel berikut:

Tabel 5. Hasil Validasi Prototypt ketiga oleh 3 validator

\begin{tabular}{clcc}
\hline No. & Aspek & Rata-rata & Keterangan \\
\hline 1. & Format Materi & 4,3 & Valid \\
\hline 2. & Bahasa yang digunakan & 4,7 & Sangat Valid \\
\hline 3. & Ilustrasi & 4,7 & Sangat Valid \\
\hline 4. & Kebenaran dan Kelogisan Isi & 4,9 & Sangat Valid \\
\hline & Rata-rata & 4,6 & Sangat Valid
\end{tabular}

Sumber: Data Primer Olahan, 2018 
Hasil penilaian kepraktisan perangkat pembelajaran LKS yang dikembangkan berdasarkan penilaian validator disajikan dalam tabel berikut:

Tabel 6. Hasil Penilaian Kepraktisan Perangkat Pembelajaran

\begin{tabular}{cccc}
\hline \multirow{2}{*}{ Perangkat Pembelajaran } & Validator & Nilai & Keterangan \\
\hline \multirow{2}{*}{ Draf LKS } & 1 & $\mathrm{~A}$ & \\
\cline { 2 - 3 } & 2 & $\mathrm{~A}$ & $\begin{array}{c}\text { Dapat Digunakan } \\
\text { setelah beberapa kali } \\
\text { revisi }\end{array}$ \\
\cline { 2 - 4 } & 3 & $\mathrm{~A}$ &
\end{tabular}

Sumber: Data Primer Olahan, 2018

Berdasarkan tabel 6 diatas, dapat disimpulkan bahwa Perangkat Pembelajaran LKS yang dikembangkan dapat digunakan karena telah beberapa kali revisi dan dapat dikatakan praktis karena semua validator menilai prototypt dengan nilai A yang berarti prototyp tidak harus direvisi kembali.

\section{Tahap Penerapan (Implementation)}

Perangkat pembelajaran yang telah direvisi berdasarkan masukan atau penilaian pada uji terbatas selanjutnya diujicobakan pada subyek penelitian kelas VIII $7 \mathrm{SMP}$ Negeri 1 Kota Bima. Perangkat pembelajaran yang diujicoba adalah LKS dan dan instrumen penelitian yaitu tes pemahaman geometri. Uji coba perangkat pembelajaran LKS bertujuan untuk penyempurnaan perangkat pembelajaran sebelum digunakan, sedangkan uji coba instrumen tes pemahaman geometri bertujuan untuk mengetahui apakah instrumen yang dikembangkan dapat mengukur kemampuan belajar siswa. Uji coba pada tahap pengembangan ini adalah uji coba perangkat pembelajaran yang dilakukan oleh guru matematika kelas VIII SMP Negeri 1 Kota Bima (Junaidin, S.Pd). Pada tahap ini dilibatkan 2 orang pengamat/observer dengan tugas yang berbeda. Seorang mengamati aktivitas siswa dan seorang lagi mengamati kemampuan guru mengelola pembelajaran. Sedangkan peneliti sekaligus berperan sebagai pengamat umum yang mengamati semua aktivitas di kelas selama pembelajaran berlangsung. Dari hasil uji coba perangkat pembelajaran, diperoleh data aktivitas siswa, data kemampuan guru mengelola pembelajaran, data pretes dan postes, dan data respon siswa. Revisi perangkat pada hasil uji coba didasarkan pada deskripsi aktivitas siswa, kemampuan guru mengelola pembelajaran, tes hasil belajar dan respon siswa.

a) Aktivitas Siswa Selama Pembelajaran 
Pengamatan terhadap aktivitas siswa selama kegiatan pembelajaran menggunakan lembar observasi aktivitas siswa. Pengamatan dilakukan oleh seorang pengamat terhadap siswa yang dilakukan sejak dimulai hingga berakhir kegiatan pembelajaran. Setiap 4 menit pengamat mengamati aktivitas siswa yang dominan dan 1 menit berikutnya pengamat menuliskan hasil pengamatannya. Kategori pengamatan menyesuaikan dengan unsur-unsur pembelajaran Cooperative Integrated Reading and Composition (CIRC) yang terdiri dari: 1) mendengarkan atau memperhatikan penjelasan guru, 2) membaca berpasangan, 3) mengidentikasi masalah, 4) menemukan kata kunci, 5) melakukan pemeriksaan dalam satu kelompok, 6) menarik kesimpulan, dan 7) perilaku siswa yang tidak relevan dengan KBM. Data aktivitas siswa selama pembelajaran diperoleh skor keidealan sebesar $96,23 \%$.

b) Kemampuan Guru Mengelola Pembelajaran

Hasil pengamatan Kemampuan Guru mengelola pembelajaran matematika dengan pembelajaran Cooperative Integrated Reading and Composition (CIRC) ditemukan bahwa terdapat beberapa aspek pengamatan yang mencapai kriteria baik dan sangat baik dari kemampuan guru sebelumnya. Hal tersebut nampak dari kemampuan guru mendorong siswa untuk mengidentifikasi masalah, menemukan kata kunci, membandingkan jawaban dengan jawaban temannya, kemampuan memimpin diskusi kelas, kemampuan menghargai pendapat siswa, antusias siswa, maupun antusias guru. Rata-rata kemampuan guru dalam mengelola pembelajaran CIRC sebesar 4,38 dan berada pada kotegori baik.

c) Respon Siswa

Dari angket respon siswa yang di isi oleh 32 siswa setelah mengikuti pembelajaran untuk materi pokok geometri lingkaran dengan model Cooperative Integrated Reading and Composition (CIRC), diperoleh hasil yaitu lebih dari $89 \%$ siswa menunjukan perasaan senang terhadap komponen pembelajaran dan menyatakan bahwa perangkat yang dikembangkan adalah baru, 98\% siswa berpendapat berminat mengikuti materi selanjutnya dengan model Cooperative Integrated Reading and Composition (CIRC), lebih dari $91 \%$ siswa menyatakan bahasa yang digunakan dalam perangkat pembelajaran jelas, dan lebih dari 95\% siswa menyatakan tertarik terhadap penampilan (tulisan, ilustrasi, gambar, dan tata letak) perangkat yang dikembangkan. Dengan demikian, dapat simpulkan bahwa respon siswa terhadap komponen pembelajaran matematika dengan 
model Cooperative Integrated Reading and Composition (CIRC) adalah positif dan perangkat pembelajaran dapat digunakan dalam proses pembelajaran.

d) Tes Pemahaman Konsep

Berdasarkan pada uji validitas didapatkan bahwa semua item soal tes pemahaman geometri sebanyak 5 (lima) nomor dinyatakan valid. Sedangkan pada uji reliabelitas dinyatakan reliabel dengan nilai sebesar 0,712 dan berkategori tinggi. Setelah dilakukan uji lapangan ditemukan data pemahaman geometri (lingkaran) rata-rata sebesar 85,43 dengan ketuntasan klasikal sebesar 87,09\%.

Pengembangan perangkat pembelajaran LKS yang dihasilkan valid untuk materi geometri di kelas VIII SMP dan Instrumen penelitian yang meliputi tes pemahaman geometri, lembar observasi aktivitas siswa, lembar observasi kemampuan guru mengelola pembelajaran dan angket respon siswa sudah siap untuk digunakan. Dengan demikian, perangkat pembelajaran LKS yang dikembangkan dapat membantu kesulitan belajar siswa dan meningkatkan pemahamannya. Hal ini sesuai dengan Penelitian yang dilakukan Mudzakir (2006) menyimpulkan bahwa apabila terdapat respon yang positif terhadap pembelajaran dengan ditandai dengan keaktifan siswa dan interaksi dengan lingkungannya selama mengikuti pembelajaran matematika maka anggapan bahwa matematika itu sulit berubah menjadi pelajaran yang menyenangkan.

\section{KESIMPULAN}

Berdasarkan hasil penelitian dan pembahasan diperoleh kesimpulan sebagai berikut:

1. Perangkat pembelajaran dengan model Cooperative Integrated Reading and Composition (CIRC) pada materi geometri (lingkaran) di kelas VIII yang berbentuk LKS adalah valid dengan kategori sangat baik setelah dilakukan beberapa kali revisi. Hal ini menunjukan bahwa perangkat yang dikembangkan dapat digunakan sebagai sumber belajar.

2. Perangkat pembelajaran dengan model Cooperative Integrated Reading and Composition (CIRC) pada materi geometri (lingkaran) di kelas VIII yang berbentuk LKS memenuhi kriteria kepraktisan setelah melalui tahap uji coba lapangan. Hal tersebut karena perangkat yang dikembangkan dapat digunakan tanpa revisi, rata-rata persentase aktivitas guru pada proses pembelajaran sebesar 4,38 atau berkategori baik, 
dan respon siswa positif yang ditunjukan dengan minat dan ketertarikannya yang tinggi dalam mengikuti pembelajaran.

3. Perangkat pembelajaran dengan model Cooperative Integrated Reading and Composition (CIRC) pada materi geometri (lingkaran) di kelas VIII yang berbentuk LKS sudah efektif. Hal tersebut dapat dilihat dari tingkat pemahaman konsep siswa dengan ketuntasan klasikal 87,09\%.

\section{DAFTAR PUSTAKA}

Acek, M. J. (2019). Penerapan Model Pembelajaran Cooperatif Integrated Reading And Composition (Circ) Dalam Meningkatkan Hasil Belajar Dan Aktivitas Belajar Siswa Kelas XI-BS 5 Pada Materi Pesan Dari Dua Buku Fiksi (Novel Dan Buku Kumpulan Puisi) Yang Dibaca Di Smk Negeri 3 Banda Aceh Pada Semester Genap Tahun Ajaran 2017/2018. Jurnal Bahasa dan Sastra, 13(1), 22-36.

Hadi, A. M., \& Wirahmad, I. (2018). Pengembangan Perangkat Pembelajaran Cooperative Integrated Reading And Composition Untuk Meningkatkan Pemahaman Geometri. AKSIOMA: Jurnal Matematika dan Pendidikan Matematika, 9(2), 23-35.

Hotimah, H., Sunardi, S., \& Suharto, S. (2014). Pengembangan Perangkat Pembelajaran Cooperative Integrated Reading And Composition (CIRC) Pokok Bahasan Kubus Dan Balok. KadikmA, 5(2).

Karimah, S. (2017). Pembelajaran Matematika Model Cooperative Integrated Reading And Composition (CIRC) Untuk Meningkatkan Kemampuan Komunikasi Matematis Materi Segiempat Kelas VII. Delta: Jurnal Ilmiah Pendidikan Matematika, 1(2), 136-143.

Rochmad, R. (2012). Desain Model Pengembangan Perangkat Pembelajaran Matematika. Kreano, Jurnal Matematika Kreatif-Inovatif, 3(1), 59-72.

Sowanto, S., Andang, A., Mutmainnah, M., \& Saputra, H. A. (2019). Kemampuan selfefficacy mahasiswa melalui bahan ajar metode statistika menggunakan hybrid learning pada tantangan revolusi industri 4.0. Supermat (jurnal pendidikan matematika), 3(2), 65-73.

Syahrir, S. (2019). Pengembangan Perangkat Pembelajaran Matematika SMP untuk Meningkatkan Kemampuan Berfikir Kreatif. Jurnal Ilmiah Mandala Education, 2(1), 436-441.

Yazid, A. (2012). Pengembangan Perangkat Pembelajaran Matematika Model Kooperatif dengan Strategi TTW (Think-Talk-Write) pada Materi Volume Bangun Ruang Sisi Datar. Journal of Primary Education, 1(1). 